\title{
Isolation, Characterization, and Localization of Heparin-binding Growth Factors in the Heart
}

\author{
Ward Casscells, ${ }^{*}$ Edith Speir, ${ }^{*}$ Joachim Sasse, ${ }^{\ddagger}$ Michael Klagsbrun, ${ }^{5}$ Paul Allen," Michael Lee, ${ }^{*}$ Benjamin Calvo, \\ Michio Chiba, " Lena Haggroth, * Judah Folkman, 5 and Stephen E. Epstein* \\ ${ }^{*}$ Cardiology Branch, National Heart, Lung, and Blood Institute, Bethesda, Maryland 20892; §Department of Surgery, Children's \\ Hospital Medical Center and Harvard Medical School, Boston, Massachusetts 02215; "Department of Anesthesiology, \\ Brigham and Women's Hospital and Harvard Medical School, Boston, Massachusetts 02115; and \\ ${ }^{\ddagger}$ Shriner’s Hospital for Crippled Children, Tampa, Florida 33612
}

\begin{abstract}
Acidic and basic fibroblast growth factors (aFGF and bFGF) are angiogenic polypeptide mitogens for cells of mesodermal and neuroectodermal origin. In this report we describe the purification from several normal human hearts (including a very fresh, nonischemic sample) of heparin-binding, acid-, heat- and trypsin-sensitive 14-18-kD peptides that crossreact with antisera against aFGF and bFGF. Further evidence includes (a) prevention of mitogenicity by protamine and by anti-bFGF, (b) displacement of ${ }^{125}$ I-bFGF from cell membranes, and (c) stimulation of capillary endothelial cell migration. Specific immunohistochemistry localized bFGF to endothelial cells and, surprisingly, to cardiac myocytes, with almost no immunoreactivity in smooth muscle cells. These peptides may function in cardiac embryogenesis, hypertrophy, atherogenesis, angiogenesis, and wound healing, and may also have endocrine, neurotropic, or vasomotor functions. (J. Clin. Invest. 1990. 85:433441.) fibroblast growth factors • angiogenesis • embryogenesis • atherogenesis • hypertrophy
\end{abstract}

\section{Introduction}

The peptides of the acidic and basic fibroblast growth factor families (aFGF and bFGF, respectively) ${ }^{1}$ have recently been purified and sequenced, and their genes have been cloned and expressed $(1,2)$. While little is known of their endogenous function, their administration in vivo leads to angiogenesis (3-5) and, in the early embryo, bFGF with transforming growth factor-beta 2 leads to induction of the mesoderm $(6,7)$. Addition of these peptides to cultures of cells of mesodermal or neuro-ectodermal origin, such as fibroblasts and endothelial and smooth muscle cells, causes proliferation (8). Because these peptides are found within cultured cells and their extracellular matrix, but not in plasma, it is presumed that they serve an autocrine or paracrine role in vivo (9-11).

Originally identified in pituitary and brain, bFGF has been found in a number of other tissues (see reference 8 ) with at

Address correspondence to Dr. Ward Casscells, National Institutes of Health, Building 10, Room 7B15, Bethesda, MD 20892.

Received for publication 17 October 1988 and in revised form 29 August 1989.

1. Abbreviations used in this paper: aFGF, acidic fibroblast growth factor; bFGF, basic fibroblast growth factor; GFU, growth factor unit; $\mathrm{hr}$, human recombinant; $L V$, left ventricle; $R A$, right atrium.

The Journal of Clinical Investigation, Inc.

Volume 85, February 1990, 433-441 least two exceptions: serum (9) and thyroid (Gospodarowicz, D., personal communication). In culture, bFGF is found in endothelial cells (9-11) and many other normal and transformed cell types, with some exceptions (12-15). aFGF is essentially restricted to brain $(5,16)$ and retina $(17)$, with small amounts identified in kidney (18) and bone matrix (19). In culture it is expressed by smooth muscle (20) and rhabdomyosarcoma (21) cells, but not by several other cell types (12-14). Little $(10)$ or no aFGF $(9,11,22)$ is expressed by cultured capillary, aortic, or umbilical vein endothelial cells. The amounts, sizes, and immunoreactivity of these peptides also differ depending on the species and organ extracted $(2,23,24)$. If present in the heart, these peptides could be involved in embryogenesis, angiogenesis, atherogenesis, hypertrophy, or healing of infarction. However, in one early study little or no bFGF was identified in the heart (25). Though there is no established correlation of tissue FGF content with indices of cell proliferation, small amounts of aFGF and bFGF would at least be consistent with the very low rates of cell proliferation in adult heart (26) and with the inability of adult heart tissue to stimulate angiogenesis in the chorioallantoic membrane assay (27). More recently, however, endothelial cell mitogenic activity was extracted from ischemic rabbit heart (28), and aFGF has been identified in cultured neonatal rat cardiac myocytes (29). There are also recent reports from our lab and others of heparin-binding mitogens from postmortem samples of normal human hearts (30) from atrial tissue of patients with heart disease (31), and from bovine, porcine, and canine hearts (32). The present investigation was undertaken to resolve the question of whether cardiac tissue contains either aFGF or bFGF, and if so, how much and in what form, and from which cells.

\section{Methods}

Patients. Samples were obtained after examination by the pathologist. Sample 1 was obtained from a 63 -yr-old man who died on 2 September 1986 of pneumonia after a 2-yr course of adenocarcinoma of the esophagus, for which he had received radiation therapy and idoxuridine. He had no history of heart disease and the heart was normal on examination $6 \mathrm{~h}$ postmortem. A 58-g portion of the left ventricle was frozen at $-70^{\circ} \mathrm{C}$ until extraction on 14 September 1986 .

Sample 2 was obtained from a 70-yr-old woman who died on 5 September 1986 of debilitation, secondary to metastatic adenocarcinoma of the breast and recent excision of a pancreatic abscess. She had received radiation therapy and tamoxifen. Her only cardiac history was that of mitral valve prolapse, which had been documented at cardiac catheterization in 1980 . Her medications were propranolol, tamoxifen, and morphine sulfate. The interval to postmortem examination was $12 \mathrm{~h}$. The heart was grossly and microscopically normal.

Sample 3 was obtained from a 25 -yr-old male victim of a motor vehicle accident who, once it was determined that he was brain dead, 
had several of his organs harvested intraoperatively for potential transplantation, with informed consent by the next of kin, and in accordance with the protocols of the New England Organ Bank and the Committee for the Protection of Human Subjects in Research, Brigham and Women's Hospital, Boston, MA. Although there was no history of heart disease, the heart was not harvested for transplantation because of the presence of pneumonia. In the operating room, $21 \mathrm{~g}$ of left ventricle were resected and immediately frozen in liquid nitrogen. Other muscle strips were tested and found to have normal contractility on the day of extraction, 28 January 1987.

Sample 4 was obtained from a 75-yr-old woman with no history of heart disease who died on 7 January 1988 of disseminated ovarian carcinoma. The heart was grossly and microscopically normal. $22 \mathrm{~g}$ of left ventricular (LV) apex and $2 \mathrm{~g}$ of right atrium (RA) were obtained 2 $\mathrm{h}$ postmortem.

Rat and dog myocardium. None of the human tissues could be cannulated and rinsed of blood. This raised the possibility that any mitogenic activity could be due to adsorbed platelet or plasma proteins. For this reason we also extracted blood-free hearts from ten 250-gmale Sprague-Dawley rats (Taconic Farms, Inc., Germantown, NY) and from a $22-\mathrm{kg}$ male foxhound and a 12-kg female beagle National Institutes of Health (NIH). These animals were cared for in accordance with the Guide for the Care and Use of Laboratory Animals (DHHS Publ. No. NIH 80-23) under the supervision of the Section on Laboratory Animal Medicine and Surgery, National Heart, Lung, and Blood Institute (NHLBI), and were free of disease. The protocol was approved by the NHLBI Animal Care and Use Committee. Briefly, the rats were anesthetized with pentobarbital $(50 \mathrm{mg} / \mathrm{kg}$ i.p.), the chest was opened, and the heart was removed and immediately perfused with saline by an aortic cannula until the perfusate became clear. Normal dog hearts were likewise removed and perfused at the termination of unrelated studies.

Tissue extraction and growth factor purification. Each myocardial sample was analyzed separately. Each was frozen in liquid $\mathrm{N}_{2}$, pulverized, and mixed with $8 \mathrm{vol}$ of cold $1 \mathrm{M} \mathrm{NaCl}$ in $10 \mathrm{mM}$ Tris, pH 4.5 or 7.4, with $1 \mathrm{mM}$ EDTA, $2 \mathrm{mM}$ PMSF, $0.5 \mathrm{mM}$ Na tetrathionate, $\mu \mathrm{g} / \mathrm{ml}$ pepstatin A (all from Sigma Chemical Co., St. Louis, MO), plus $1 \mu \mathrm{g} / \mathrm{ml}$ leupeptin (Boehringer Mannheim Biochemicals, Indianapolis, IN). The tissue was then briefly homogenized by Polytron (Lucerne, Switzerland) and centrifuged at $50,000 \mathrm{~g}$ for $60 \mathrm{~min}$ at $4^{\circ} \mathrm{C}$. The fat was skimmed and the supernatant diluted to $0.5 \mathrm{M} \mathrm{NaCl}$, verified by conductivity testing (Radiometer, Copenhagen, Denmark). It was then adsorbed at $4^{\circ} \mathrm{C}$ overnight (with gentle rocking) to swollen heparinSepharose $(1 \mathrm{ml}$ per $10 \mathrm{~g}$ of wet tissue; Pharmacia Fine Chemicals, Piscataway, NJ) equilibrated with $0.5 \mathrm{M} \mathrm{NaCl}$ and $10 \mathrm{mM}$ Tris. The nonadsorbed supernatant was decanted and the beads were poured into a column and washed with 20 column vol of $0.5 \mathrm{M} \mathrm{NaCl}$ with 10 $\mathrm{mM}$ Tris. The column was then eluted with $0.6-\mathrm{ml}$ fractions of $\mathrm{NaCl}$, as either a continuous or stepped gradient of $1.1,1.5$, and $2 \mathrm{M} \mathrm{NaCl} / 10$ $\mathrm{mM}$ Tris (rate, $20 \mathrm{ml} / \mathrm{h}$ ) for a total elution volume of $1 \mathrm{ml} / \mathrm{g}$ wet weight of heart. The fractions were collected in iced polypropylene tubes and frozen at $-80^{\circ} \mathrm{C}$.

SDS-PAGE. SDS-PAGE was carried out by a modified Laemmli technique using 10-20\% gradient mini-gels (ISS; Hyde Park, MA) and prestained and unstained molecular weight markers (ISS). All samples were adjusted to equal ionic strengths, usually $0.8 \mathrm{M}$, reduced with beta mercaptoethanol, and heated to $90^{\circ} \mathrm{C}$ for $3 \mathrm{~min}$. Additional molecular weight markers were human recombinant (hr) bFGF and aFGF (154 amino acid constructs), which usually migrate at 17,500 (a generous gift of Dr. L. Cousens and Dr. P. Barr, Chiron Corp., Emeryville, $\mathrm{CA}$ ). The gels were run for $2.5 \mathrm{~h}$ at $35 \mathrm{~mA}$ and $100-150 \mathrm{~V}$ as mirror images so that half the gel could then be stained by the silver technique using the ISS kit and the other half of the gel immediately placed in transfer buffer.

Western immunoblotting. The gels were immediately transferred to $0.05-\mu \mathrm{m}$ pore nitrocellulose paper (Schleicher \& Schuell, Inc., Keene, $\mathrm{NH}$ ) at $30 \mathrm{~V}, 200 \mathrm{~mA}$, over $45 \mathrm{~min}$ in a Polyblot semi-dry apparatus (American Bionetics, Hayward, CA) using the manufacturer's speci- fied anode and cathode buffers. The proteins were then stained as described below.

Antibodies. Several polyclonal antisera were raised in rabbits (by Dr. Sasse) using peptide replicates of bovine bFGF (original numbers: $1,2,3$ = PAL), 1-12, 33-43, and 135-145, synthesized as described (33). In Western blotting these detect $10 \mathrm{ng}$-of hrbFGF and $100 \mathrm{ng}$ hraFGF ( $10 \%$ crossreactivity). Rabbit anti-bFGF ${ }_{1-24}$, a generous gift of Dr. Andrew Baird (Whittier Institute, La Jolla, CA), detects 5 ng hrbFGF (and $100 \mathrm{ng} \mathrm{hraFGF)} \mathrm{in} \mathrm{Western} \mathrm{blotting.} \mathrm{Its} \mathrm{epitope,} \mathrm{residues}$ $11-15$, is without homology for predicted products of the oncogenes int-2, hst (K-FGF), and FGF-5.

Dr. Denis Gospodarowicz (Cancer Research Institute, University of California, San Francisco, CA) generously provided an IgG-purified rabbit polyclonal antiserum ("cat," raised against whole denatured hrbFGF) which detects $10 \mathrm{ng}$ hrbFGF in a Western blot at a 1:1,000 dilution. $10 \mu \mathrm{l}$ blocks the mitogenic effect of $0.4 \mathrm{ng}$ bFGF.

Polyclonal antisera against human aFGF residues 7-16 and 50-82 (numbered as in the original sequence, beginning FNLR . . .) were raised by $\mathrm{Dr}$. Sasse as above. We also used a polyclonal anti-aFGF $22-155$ (a generous gift of Dr. Michael Jaye, and numbered according to his deduced sequence, beginning AEGE ....). All three detect $5 \mathrm{ng}$ hraFGF in a Western blot with $1-10 \%$ crossreactivity with hrbFGF Anti-aFGF $22-155$ also crossreacted with BSA.

Dot blotting. 10- or $20-\mu \mathrm{l}$ samples were applied to $0.05-\mu \mathrm{m}$ pore nitrocellulose sheets clamped in a Minifold II apparatus from Schleicher \& Schuell, Inc. The samples were allowed to adsorb for several hours until dry. Nonspecific sites were then blocked by incubating in $5 \mathrm{mg} / \mathrm{ml}$ gelatin in PBS for $30 \mathrm{~min}$ and then in $10 \%$ goat serum in PBS for $60 \mathrm{~min}$. The samples were rinsed with three 1-min washes of PBS with $0.1 \%$ Tween and then the primary antiserum was applied and allowed to incubate for 10-12 h. The dilutions were as follows: anti-bFGF $1-24,1: 80,000$; anti-bFGF 33-43 $_{1}, 1: 1,000$; anti-bFGF cat, 1:4,000; anti-aFGF $50-82,1: 20,000$; anti-aFGF ${ }_{7-16}, 1: 10,000$; and anti-aFGF $22-155,1: 40,000$. After three 5-min washes the samples were incubated with biotinylated goat anti-rabbit IgG (Zymed) at 1:1,000 dilution for $1 \mathrm{~h}$ followed by three washes ( $5 \mathrm{~min}$ each). They were then incubated in the biotinylated peroxidase-streptavidin complex (Amersham Corp., Arlington Heights, IL) at a dilution of 1:330 for half an hour, followed by application of the substrates that consisted of $16 \mu \mathrm{l}$ of $30 \%$ hydrogen peroxide in $40 \mathrm{ml}$ of PBS with $24 \mathrm{ng}$ of 4-chloro-lnaphthol in $8 \mathrm{ml}$ methanol (all from Sigma Chemical Co.). The color intensities were graded by eye using a $1-4+$ scale.

Cell culture. Balb/c 3T3 mouse fibroblasts, clone A31 (American Type Culture Collection, Rockville, MD), were grown in $75-\mathrm{cm}^{2}$ plastic flasks (Corning Glass Works, Oneonta, NY) in DME with 10\% calf serum and $2 \mathrm{mM}$ glutamine, $50 \mathrm{U} / \mathrm{ml}$ penicillin, and $50 \mu \mathrm{g} / \mathrm{ml} \mathrm{strep-}$ tomycin, $0.2 \mu \mathrm{m}$-filtered (Nalge Co., Rochester, NY), in a humidified $37^{\circ} \mathrm{C}$ incubator with $10 \% \mathrm{CO}_{2}$. All reagents were from Biofluids (Rockville, MD). The cells were negative for mycoplasma by Genprobe (Fisher Scientific Co., Pittsburgh, PA). They were split at $70 \%$ confluence with $0.05 \%$ trypsin-EDTA at a split ratio of $1: 1,000$. Cells were not used after passage 10 .

Bovine adrenal capillary endothelial cells were isolated as described (34) and maintained in gelatin-coated T-75 flasks in DME (low glucose) with $10 \%$ calf serum, $1 \mathrm{ng} / \mathrm{ml}$ of bFGF every other day, $50 \mathrm{U} / \mathrm{ml}$ penicillin, and $50 \mu \mathrm{g} / \mathrm{ml} \mathrm{streptomycin,} \mathrm{in} \mathrm{a} \mathrm{humidified} 37^{\circ} \mathrm{C}$ incubator with $5 \% \mathrm{CO}_{2}$. Cells were passaged weekly at a split ratio of 1:64 and studied between passages 6 and 9 .

Fibroblast mitogenicity was assayed using the Balb/c 3T3 fibroblasts as described (19).

Capillary endothelial cells were plated at $10,000 / 2 \mathrm{ml}$ in gelatincoated 35-mm Falcon dishes (Becton Dickinson, Oxnard, CA) in 10\% calf serum, with $0-5 \mathrm{ng} / \mathrm{ml}$ bFGF on days 1 and 3 as a standard curve, and 1,2 , or $3 \mu$ of the column fractions (or elution buffer, as control) on days 1 and 3. Cells were trypsinized and counted by electronic particle counter (Elzone) on day 5.

Protein quantification. Protein content was measured by the Bradford method using kits from Bio-Rad Laboratories. 
Inactivation studies. Active $1.5 \mathrm{M}$ fractions, and $\mathrm{bFGF}$ as positive control, were inactivated by boiling for $10 \mathrm{~min}$, by acidication in $0.1 \mathrm{~N}$ $\mathrm{HCl}$ followed by neutralization, or by L-1-tosylamide-2-phenylethyl chloromethyl ketone trypsin, $50 \mu \mathrm{g} / \mathrm{ml}$ at $37^{\circ} \mathrm{C}$ for $100 \mathrm{~min}$, to which $150 \mu \mathrm{g} / \mathrm{ml}$ soybean trypsin inhibitor was added before (control) or after the incubation.

FGF receptor blockade. Protamine $(5 \mu \mathrm{g} / \mathrm{ml})$, which blocks the FGF and platelet-derived growth factor receptors (35), was used to block the mitogenicity of the $1.5 \mathrm{M}$ fractions, and tested with and without hrbFGF as positive and negative controls.

Anti-bFGF blocking antiserum. $20 \mu \mathrm{l}$ of a 1:1,000 dilution of Dr. D. Gospodarowicz's antiserum (described above) was added to Balb/c 3T3 cells alone (as background) or just before addition of $0.8 \mathrm{ng}$ hrbFGF (as control) or $0.5 \mu \mathrm{l}$ of a $2 \mathrm{M}$ heparin column fraction of human heart, to determine whether that fraction's mitogenicity was due to bFGF.

Estimates of FGF equivalents. Acidic FGF-like mitogenicity (that eluting between 0.9 and $1.3 \mathrm{M} \mathrm{NaCl}$ by gradient or with $1.1 \mathrm{M}$ stepped elution) was estimated by comparison with a standard curve using recombinant aFGF or bFGF (generous gifts of $L$. Cousens and P. Barr, Chiron Corp.), or from serum growth factor units (GFUs) using the convention $1 \mathrm{GFU}=1 / 2$ (maximal $3 \mathrm{~T} 3$ thymidine incorporation in response to serum minus background). In some assays there was substantial overlap of the two peaks, and immunoblotting (see below) indicated that some bFGF eluted with $1.3 \mathrm{M} \mathrm{NaCl}$, while some aFGF eluted at $1.5 \mathrm{M} \mathrm{NaCl}$. Our assumption that these overlaps cancel out is one of several possible sources of error in quantitation of aFGF and bFGF contents.

Basic FGF-like mitogenicity was assumed to be that eluting between 1.4 and $2 \mathrm{M}$ by gradient, or by 1.5 and $2 \mathrm{M}$ stepped elutions. In these Balb/c $3 T 3$ assays $1 \mathrm{ng} / \mathrm{ml}$ of purified pituitary bFGF or $2 \mathrm{ng}$ of brain aFGF (generous gifts of D. Gospodarowicz) or $1 \mathrm{ng} / \mathrm{ml} \mathrm{hrbFGF}$ or $2 \mathrm{ng} / \mathrm{ml} \mathrm{hraFGF}$, equaled $3 \mathrm{GFUs}$ (though depending on the culture conditions bFGF is often 10-fold more potent than aFGF, especially for capillary endothelial cell proliferation).

Radioreceptor assay. BHK-21 fibroblasts were grown as described by Neufeld and Gospodarowicz (36) and assayed in confluent monolayer culture at $4^{\circ} \mathrm{C}$. Human rbFGF (Chiron Corp.) was iodinated with iodogen as described, to an estimated sp act of $2 \times 10^{5} \mathrm{cpm} / \mathrm{ng}$ ) (36).

After $2 \mathrm{~h}$ at $37^{\circ} \mathrm{C}$ in serum-free DME with $0.15 \%$ gelatin, cells were washed, blocked with $2 \mu \mathrm{g} \mathrm{bFGF} / 16-\mathrm{mm}$ well, and incubated for $2 \mathrm{~h}$ at $4^{\circ} \mathrm{C}$ with ${ }^{125} \mathrm{I}-\mathrm{bFGF}(0.432 \mathrm{ng} /$ well) plus $0.2-20 \mathrm{ng} /$ well bFGF. Low affinity binding was removed by a 2-min wash with $2 \mathrm{M} \mathrm{NaCl}$ and radioactivity was extracted with Triton X-100 as described by Moscatelli (37).

Cell migration assay. Migration was assayed using $10^{5}$ freshly trypsinized, newly confluent capillary endothelial cells, seeded onto polyvinyl pyrrolidone-free filters (Nucleopore Corp., Pleasanton, CA), $6 \mu \mathrm{m}$ pore size, and coated with $5 \mu \mathrm{g}$ collagen IV (Collaborative Research Inc., Lexington, MA) in blind well Boyden chambers, essentially as described (38). Cells on the lower surface were counted under the microscope after $4 \mathrm{~h}$ of migration at $37^{\circ} \mathrm{C}$. No attempt was made to distinguish chemokinetic from chemotactic activity by checkerboard assay.

Immunohistochemistry. Rat hearts were fixed by perfusion with $10 \%$ formalin. 6- $\mu \mathrm{m}$ paraffin sections were rehydrated and endogenous peroxidases were quenched by $2 \% \mathrm{H}_{2} \mathrm{O}_{2}$ in methanol for $30 \mathrm{~min}$ at $24^{\circ} \mathrm{C}$, washed with a surfactant (1:400 BLJ-35; Sigma Chemical Co.), and partially digested with hyaluronidase $(2 \mathrm{mg} / \mathrm{ml}$ in acetate buffer, pH 5.5, for $15 \mathrm{~min}$ at $24^{\circ} \mathrm{C}$ ) (39). Slides were again washed, blocked with $5 \%$ goat serum, washed, and incubated with either anti-bFGF ${ }_{1-24}$ or anti-bFGF (cat) at $4^{\circ} \mathrm{C}$ overnight. Goat anti-rabbit antiserum ( $1: 200,1 \mathrm{~h}, 24^{\circ} \mathrm{C}$ ), ABC complex (Vector Laboratories, Burlingame, CA), and diaminobenzidine were used according to the manufacturer's instructions. The counterstain was $1 \%$ methyl green. Specificity was indicated by the virtual absence of stain with nonimmune serum, or with immune serum if sections were prewashed with $2 \mathrm{M} \mathrm{NaCl}$ to remove bFGF associated with heparan sulfate. Almost no stain was seen when anti-bFGF ${ }_{1-24}$ was adsorbed with excess hrbFGF but not with hraFGF. Peptide adsorption was not tested with cat, but the stain pattern was similar to that with anti-bFGF 1-24 .

\section{Results}

\section{Mitogen assays}

Fig. 1 shows the mitogenic effects, for fibroblasts and capillary endothelial cells, of a representative extract (heart No. 2) of human LV myocardium extracted in high ionic strength buffer at pH 4.5. Mitogenic activity for 3T3 fibroblasts and capillary endothelial cells was present in fractions that eluted from heparin-Sepharose columns in broad peaks at 1 and $1.5 \mathrm{M} \mathrm{NaCl}$, consistent with the heparin affinity of aFGF and bFGF, respectively. The other hearts yielded peaks that were less well separated, with the bFGF peak generally larger. No other proliferation studies were performed with the $1 \mathrm{M}$ fractions. However, further evidence of similarity, if not identify, of the $1.5 \mathrm{M}$ column fractions with bFGF is indicated by the loss of activity with boiling, trypsinization, or acid treatment. The antiserum (cat) to whole bFGF and the FGF receptor blocker protamine each reduced the mitogenicity of these fractions by $>90 \%$ (data not shown).

To exclude the possibility that the mitogenic activity was not from heart tissue, but from residual plasma or serum, we analyzed platelet-poor plasma, whole blood serum, and fresh uncentrifuged whole blood from three healthy male volunteers, ages 23, 29, and 31 yr (data not shown). There was little or no heparin-binding mitogenic activity in any of these 40-ml samples, which would represent 10 times the amount of blood in a perfused $20-\mathrm{g}$ sample of myocardium. The data suggest

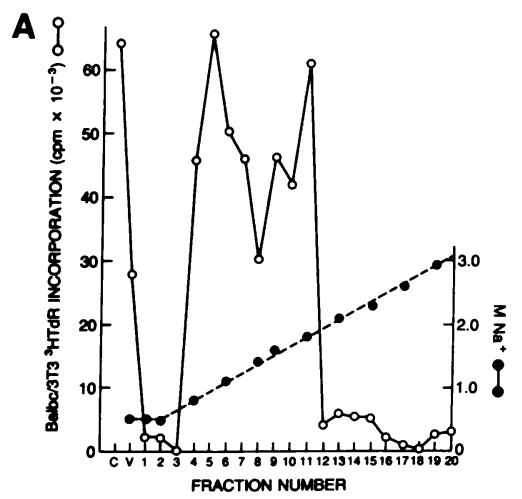

Figure 1. A, Mitogenicity for Balb/c-3T3 cells of crude human heart supernatant $(c$ on $x$ axis), non-heparinbinding supernatant $(v$ on $x$-axis), and heparinSepharose column fractions. Background counts have been subtracted. Counts of triplicate wells were within $10 \%$ of the mean. This experiment was repeated at least once for each heart. $B$, Proliferation of capillary endothelial cells in response to recombinant bFGF

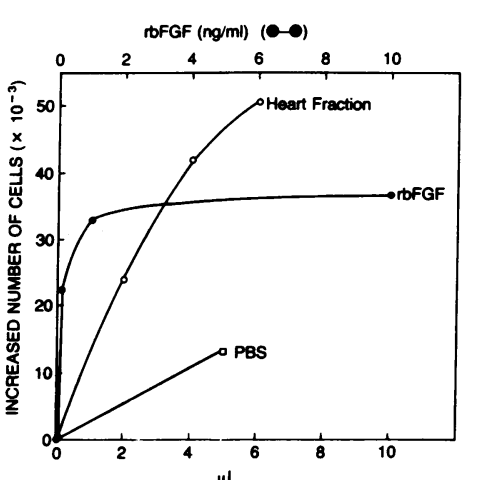
$(r b F G F), 1.5 \mathrm{M}$ heparin column fractions of heart extract, or PBS control. Initial numbers of attached cells at $4 \mathrm{~h}$ $(\sim 4,000)$, when test substances were added, have been subtracted. Counts of triplicate wells were within $15 \%$ of the mean. The experiment was repeated once. 


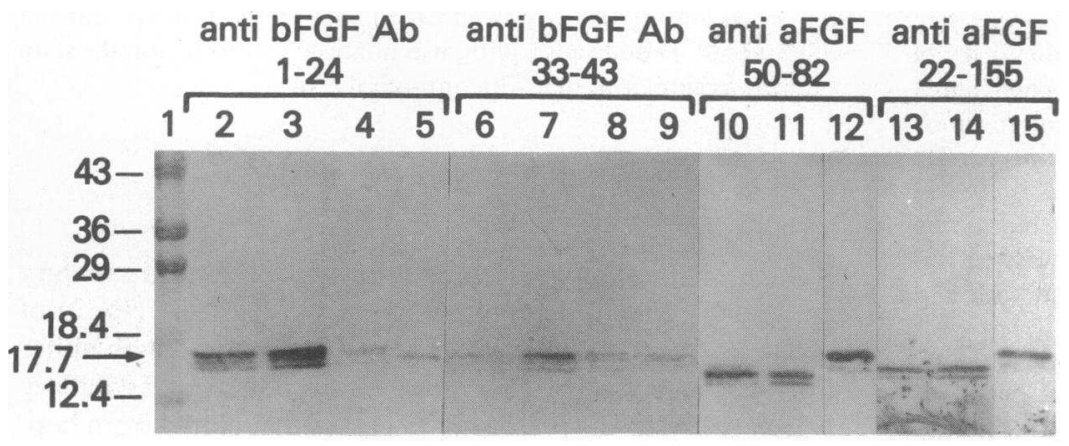

Figure 2. Western blots of fractions of human heart No. 3 eluted from heparin-Sepharose with $1.5 \mathrm{M}$ $\mathrm{NaCl}$ and incubated with anti-bFGF ${ }_{1-24}$ and anti$\mathrm{bFGF}_{33-43}$, and of 1.1-M fractions incubated with anti-aFGF $50-82$ or anti-aFGF $22-155$. Lanes 5 and 9 are recombinant bFGF. Lanes 12 and 15 are recombinant bFGF. Lanes $2-4,6$, and 7 are 1.5-M fractions. Lanes $10,11,13$, and 14 are 1.1-M fractions. Preadsorption of anti-bFGF resulted in no stain (not shown). Similar results were obtained with other hearts assayed by these antisera and by antibFGF $_{135-145}$, anti-hrbFGF (cat), and anti-aFGF ${ }_{7-16}$. However, no aFGF immunoreactivity was found in heart No. 4.

that there could be no more than 10 ng of aFGF or bFGF per $\mathrm{ml}$ of blood. We also identified these heparin-binding immunoreactive mitogens from rat and canine hearts after perfusing them until free of blood (data not shown).

\section{Western blotting}

1.5 $\mathrm{M} \mathrm{NaCl}$ eluate. The heart-derived mitogen that eluted at $1.5 \mathrm{M} \mathrm{NaCl}$ reacted with antibodies raised against bFGF residues 1-24 and 33-43 (Fig. 2). Not shown are Western blots demonstrating reactivity with the antisera to hrbFGF and to the $\mathrm{COOH}$ terminus, as well as a dot blot showing reactivity with a polyclonal antiserum raised against amino acids 1-12. No reaction product was detected in the absence of immune serum, or if the immune serum was combined with excess hrbFGF (not shown).

Bands were seen only at $M_{\mathrm{r}} 14 \mathrm{kD}$ in the first heart, but in subsequent hearts bands were noted at 18,17 , and $16 \mathrm{kD}$, consistent with the well-recognized $\mathrm{NH}_{2}$-terminal cleavage of bFGF by acid proteases. We also noted that $14-\mathrm{kD}$ bands retained some $\mathrm{NH}_{2}$-terminal immunoreactivity, suggesting that cleavage can also occur at the $\mathrm{COOH}$ terminus. After a few days to weeks at $4^{\circ} \mathrm{C}$, impure fractions often revealed only 14-16-kD bands, suggesting that a protease can copurify with the mitogen (Fig. 3).

The detection of $18-\mathrm{kD}$ immunoreactivity, migrating more slowly than the 154 residue hrbFGF that corresponds to the published gene sequence, is consistent with other recent reports of extended forms of bFGF (23).

$1 \mathrm{M} \mathrm{NaCl}$ eluate. The mitogen eluting at $1 \mathrm{M}$ exhibited

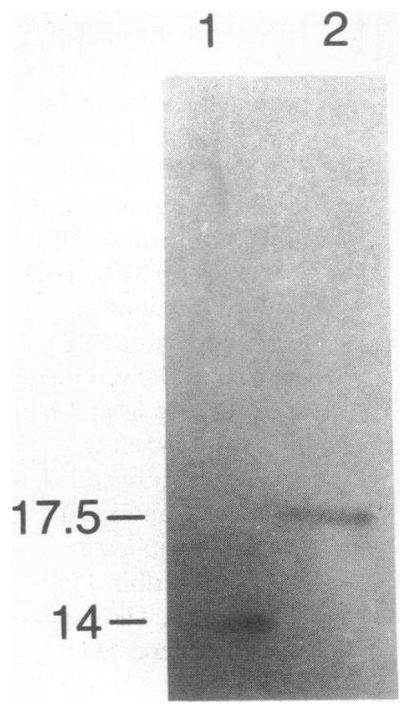

Figure 3. SDS polyacrylamide gel, stained with silver, of mitogen eluted by $1.5 \mathrm{M} \mathrm{NaCl}$ from heparin-Sepharose column and, several weeks later, separated from high molecular weight contaminants by gel filtration, by which time the mitogen (lane 1 , now purified to single band homogeneity), which formerly migrated with the recombinant bFGF (lane 2), had apparently been cleaved to $M_{\mathrm{r}} 14 \mathrm{kD}$. Unmarked lane, molecular weight markers $\times 10^{-3}$. immunoreactivity with antibodies raised to residues 7-16 and 50-82 of bovine aFGF and to a polyclonal antibody raised against whole human aFGF, as shown in Fig. 2. Gel electrophoresis usually indicated a mitogen of $\sim 15,000 M_{\mathrm{r}}$, but immunoreactivity was occasionally noted at $17 \mathrm{kD}$ as well. Some bFGF immunoreactivity was usually seen also, especially in the later $1 \mathrm{M}$ fractions.

\section{Purification and quantification of $a F G F$ and $b F G F$}

After one step of heparin-Sepharose chromatography silverstained SDS polyacrylamide gels usually revealed 6-20 bands in the $1.1 \mathrm{M}$ fractions, 3-10 bands in the $1.5 \mathrm{M}$ fractions, and 2-3 bands in the $2 \mathrm{M}$ fractions. Subsequent purification to single band homogeneity (Fig. 3) was achieved by gel filtration, or cation-exchange chromatography, or in one case by two more steps of heparin-Sepharose chromatography. In heart No. 1, single band purity was achieved after only one step of heparin-Sepharose chromatography.

The content of aFGF and bFGF were estimated after one cycle of heparin-Sepharose chromatography, based on GFU, substantiated by estimates of immunoreactivity based on slot blots using recombinant peptides as standard curves (density of reaction product correlated with amounts of hrbFGF or hraFGF from $100 \mathrm{pg}$ to $25 \mathrm{ng}$ ). Estimates for $\mathrm{LV}$ samples are shown in Table $I$. The right atrial sample from patient 4 yielded only $30 \mathrm{ng} / \mathrm{g}$. However, for unknown reasons there was only $10 \%$ as much protein in the supernatant of the atrium compared with that of the ventricle, so that the atrium and ventricle had equal mitogenicity when expressed as bFGF equivalents per milligram of supernatant protein. No other human samples were available to repeat the experiment. However, bovine RA and LV yielded, per gram of wet tissue, similar amounts of bFGF (calculated from serum GFUs), $380 \mathrm{ng}$ (RA) vs. $400 \mathrm{ng}(\mathrm{LV})$ per gram, and similar amounts of protein in the supernatant of the crude homogenate, $26.6 \mathrm{mg}$ (RA) vs. $24.6 \mathrm{mg}(\mathrm{LV})$. However, the same heart yielded more aFGF in the $\operatorname{LV}(200 \mathrm{ng} / \mathrm{g})$ than in the RA $(100 \mathrm{ng} / \mathrm{g})$.

Table I. Amounts of aFGF and bFGF (nanograms/gram tissue) from LV Samples of Four Human Hearts

\begin{tabular}{lcccr}
\hline & \multicolumn{4}{c}{ Sample No. } \\
\cline { 2 - 5 } & 1 & 2 & 3 & 4 \\
\hline aFGF $(n g / g)$ & 250 & 260 & 454 & 0 \\
bFGF $(n g / g)$ & 218 & 130 & 388 & 295 \\
\hline
\end{tabular}

Amounts are estimated from Balb/c 3T3 mitogen assays as described in Methods. 
As a preliminary attempt to detect organ-specific differences, whole brain and whole heart tissue from the same dog were homogenized in $1 \mathrm{M} \mathrm{NaCl}, \mathrm{pH} 4.5$, and subjected to heparin-affinity chromatography in the usual fashion. These extractions yielded the following: protein, $5 \mathrm{mg} / \mathrm{g}$ (brain), 6.2 $\mathrm{mg} / \mathrm{g}$ (heart); aFGF, $0.2 \mu \mathrm{g} / \mathrm{g}$ (brain), $0.36 \mu \mathrm{g} / \mathrm{g}$ (heart); bFGF 2 $\mu \mathrm{g} / \mathrm{g}$ (brain), $4.2 \mu \mathrm{g} / \mathrm{g}$ (heart).

The variation between patients could reflect interindividual differences based on age, sex, clinical condition, or other factors. However, there were also differences in the time intervals between death and tissue harvesting, and time in the freezer, as well as some differences in purification procedures. For example, we have noted that recovery is influenced by the volume, $\mathrm{pH}$, and ionic strength of the homogenization buffer, the speed of centrifugation, and the freshness of heparin-Sepharose and its lot-to-lot variability. The degree of purification obtained with one cycle of heparin-Sepharose chromatography varies from $\sim 1,000$ - to 6,000 -fold. Thus, even with simultaneous mitogen and immunoassays it is difficult to determine whether there are interindividual or interspecies variations based on so few samples.

Estimates of recovery are likewise problematic. The supernatant of the crude homogenate (the conventional denominator) necessarily excludes any growth activity in the pellet. Secondly, the heart or the homogenization buffer may contain inhibitors of 3T3 cell growth, causing the content of FGF peptides in the supernatant to be underestimated and their recovery overestimated. The presence of mitogens other than FGFs in the heart would lead to the opposite error.

\section{Radioreceptor assay}

The 1.5 M column fractions displaced ${ }^{125} \mathrm{I}-\mathrm{bFGF}$ from monolayers of BHK-21 cells in a manner similar to hrbFGF (Fig. 4). The 1.1 M fractions were not tested.

\section{Cell migration assay}

The $1.5 \mathrm{M}$ column fractions duplicated the effects of hrbFGF in promoting migration of capillary endothelial cells (Fig. 5).

\section{Immunohistochemistry}

Specific staining for immunoreactive bFGF was prominent in rat ventricular cardiac myocytes and arterial endothelium (Fig.

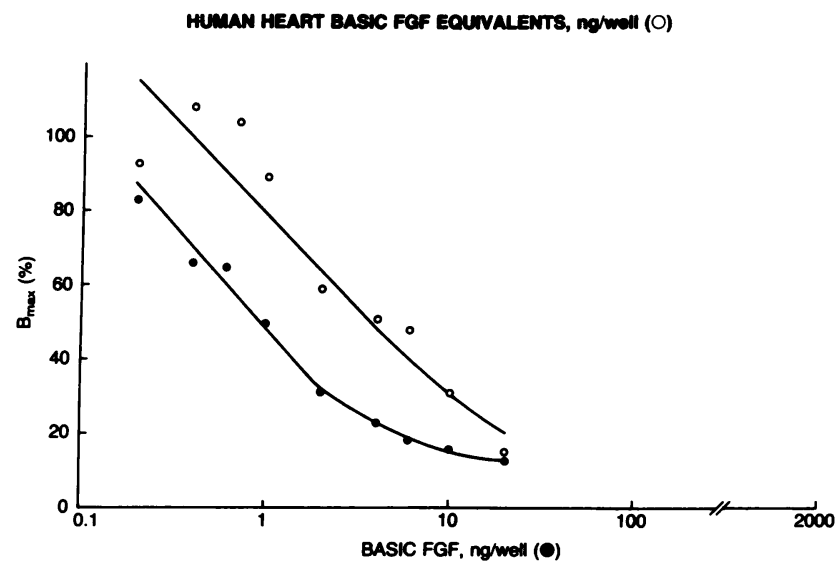

Figure 4. Radioreceptor assay for bFGF. ${ }^{125}$ I-bFGF bound to BHK-21 cell monolayers was displaced by hrbFGF and heart-derived bFGF as described in Methods. Nonspecific binding (6\%) was subtracted from values shown. Counts of triplicate wells were within $15 \%$ of the means. Assay was repeated once.

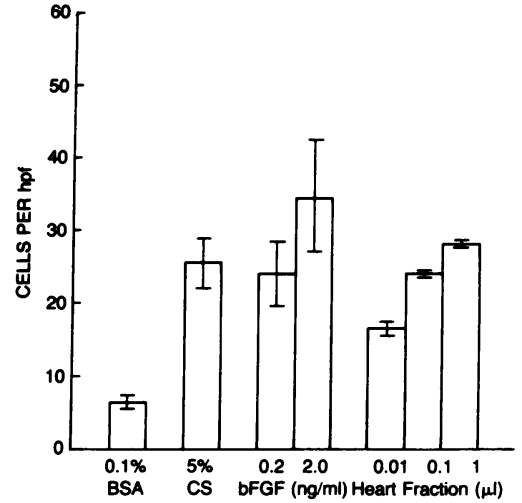

Figure 5. Boyden chamber assay of migration of capillary endothelial cells to BSA, recombinant bFGF, $5 \%$ calf serum $(C S)$, or aliquots of $1.5 \mathrm{M}$ heparin column fractions of human heart. Values are means \pm SD of duplicate filters. The experiment was repeated once.

6). Vein and capillary staining was faint and variable, perhaps reflecting variable degrees of exposure or masking of the epitopes due to lot-to-lot variation in the fixative and hyaluronidase. Arterial adventitium revealed bFGF immunoreactivity, but medial layers were very faint or unstained.

\section{Discussion}

These data indicate that normal human atrial and ventricular myocardium contain mitogens for fibroblasts and endothelial cells and that these mitogens resemble aFGF and bFGF in their molecular weight and affinity for heparin, their sensitivity to heat, acid, and trypsin, and their immunoreactivity. Fractions eluting from the heparin column between 1.2-2 M $\mathrm{NaCl}$, the elution profile for bFGF, competed with radiolabeled bFGF for cell membrane binding and promoted migration of capillary endothelial cells. Their mitogenic effects were blocked by anti-bFGF antiserum and also by protamine, which occupies the bFGF receptor (35). There was also some mitogenic activity with little heparin affinity, which has yet to be characterized.

In theory, we could have isolated fragments of the protein products of the recently described oncogenes int-2 (40), hst (41) (Kaposi's FGF) (42), or FGF-5 (43). This is unlikely for a number of reasons. First, these oncogenes were discovered in malignant tissues; int-2 mRNA, in particular, has been sought in normal tissues and has not been detectable except in embryonic tissue. Second, although there is considerable homology of these oncogenes to bFGF (and less to aFGF), there is no significant homology with bFGF residues 1-24, against which two of our antisera were raised. Indeed, anti-bFGF ${ }_{1-24}$ was recently found not to crossreact with the hst product Kaposi's FGF (Halaban, R., unpublished observations). Nor does our anti-bFGF ${ }_{33-43}$ detect the int-2 or hst products (Klagsbrun, $M$., unpublished observations).

Were these mitogens from blood or heart? Another concern was that our mitogenic activity might have been attributable to blood in the vasculature of the hearts, since being frozen they could not be rinsed. Vlodavsky et al. have reported that serum does not contain heparin-binding endothelial mitogens (9). However, there is one report of bFGF-like immunoreactivity in serum (44), and bFGF has been purified from macrophages and from a monocyte line (24). In addition, platelets support endothelial growth $(45,46)$. For these reasons we looked for heparin-binding mitogenic activity in human blood and could not find any. Furthermore, blood-free dog and rat hearts yielded heparin-binding mitogens with similar immunoreactivity. Finally, the immunohistochemical staining makes it 

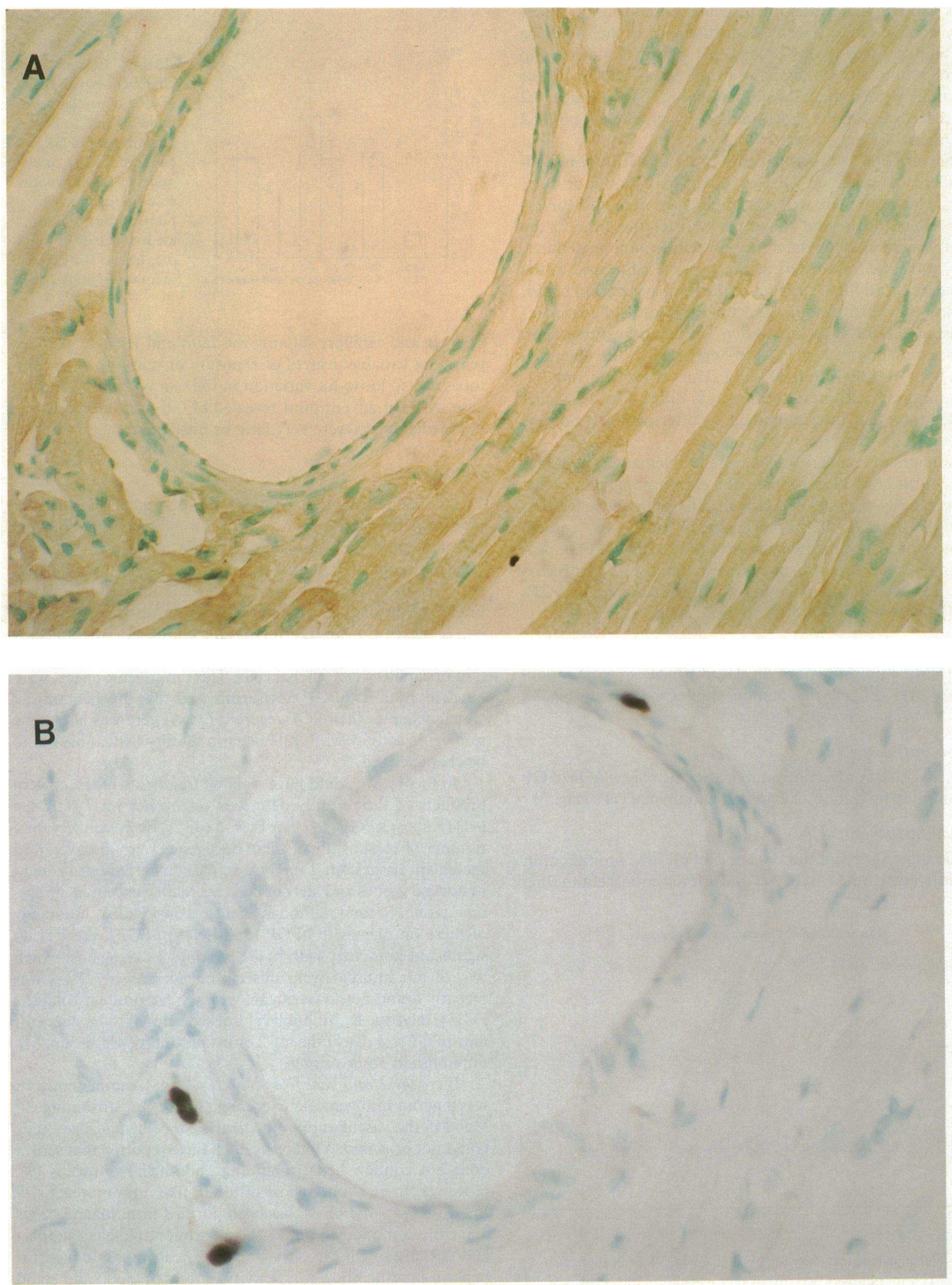
very likely that the activity we have detected derives from the myocardium and not from blood.

Are these mitogens an artifact of agonal synthesis? We studied normal tissue to exclude the possibility that any FGF-like activity was due to such processes as atherosclerosis, hypertrophy, or malignancy. Galloway et al. (28) had found endothelial mitogenic activity in ischemic rabbit heart, and we had previously isolated heparin-binding mitogens from ischemic canine (47) and postmortem human myocardium (30). These findings, plus earlier reports of the lack of mitogenic activity in crude heart extracts (25) or of angiogenic activity of adult heart tissue grafts (27) in the chorio-allantoic membrane, together with the rarity of cell division in the adult heart (26), suggested the possibility that bFGF and aFGF might be absent in normal heart, but rapidly synthesized in response to ischemia. The well-established decline in overall protein synthesis in ischemic myocardium (48) did not preclude such a possibility, since there is some evidence of new synthetic activity in the acutely stressed heart (49). Stress protein synthesis in response to ischemia (50) and platelet-derived growth factor synthesis by dying cells (51) are well-documented responses that suggest that specific FGF synthesis could occur as an agonal event. Hence, we made certain to obtain a sample of absolutely fresh, nonischemic myocardium, and this sample (No. 3) did contain both aFGF and bFGF.

Amounts of myocardial FGF peptides. Differences in age, sex, and clinical conditions preclude any precise comparison of the amounts in the four samples. Nor can exact comparisons be made with FGF yields from other organs, since we were unable to obtain comparably fresh brain or pituitary tissue from the same patients. We did compare brain and heart from the same dog, in parallel, and found that the heart contained more aFGF and bFGF than brain.

We were also surprised to find in most hearts somewhat more aFGF than bFGF. Similar findings have been reported for brain tissue. (The apparent absence of aFGF in one heart may be an artifact or may reflect the greater susceptibility of aFGF to proteolysis). We considered the possibility that this finding was a reflection of the particular extraction protocol, but roughly the same results were obtained despite varying $\mathrm{pH}$, ionic strength, and other homogenization conditions (Speir, E., unpublished observations).

Sizes of myocardial FGF-like peptides. The detection of a slightly longer form of bFGF in the heart compared with that found in most tissues has some recent precedence in the detection of a $25-\mathrm{kD}$ form of bFGF, extended at the amino terminus, in guinea pig brain (23).

It also remains unclear whether different sizes of FGF represent alternative sites of initiation of transcription or translation, differential splicing, variable polyadenylation, or processing in vivo or during the extraction procedure. We have purified shorter forms of both aFGF and bFGF, migrating at 14, 15 , and $16 \mathrm{kD}$, from canine, human, and rat myocardium, especially when protease inhibitors were omitted from the homogenization buffer, and have also observed in the human and rat column fractions that the $17-$ and $18-\mathrm{kD}$ forms of
bFGF can be cleaved to $14 \mathrm{kD}$ over the course of a few weeks at $4^{\circ} \mathrm{C}$ even when nearly homogeneous by silver stain. This suggests that small amounts of a heparin-binding protease, from serum or myocardium, such as plasmin, trypsin, thrombin, or a cathepsin, may copurify with bFGF on heparin affinity columns. The consistently greater tendency of aFGF, compared with bFGF, to elute as a mitogen of $M_{\mathrm{r}} 14 \mathrm{kD}$, may reflect either the greater sensitivity of aFGF to degradation by thrombin (52) or its lesser affinity for heparin, which protects both mitogens against trypsin (53).

Cellular localization of $b F G F$. With the exception of the corneal matrix, the localization of bFGF in vivo is not known. In this study we found prominent bFGF immunoreactivity in the arterial endothelium with faint stain in capillary and venular endothelium. The staining was more evident in some cells than others, reflecting either methodological artifact or capillary heterogeneity. Regions where the endothelium had become separated from the vessel, either by enzyme digestion or microtomy, suggested that bFGF was in the subendothelial matrix as well as in the endothelial cells, as previously shown in vitro $(10,11,22)$. The resolution of light microscopy has not allowed us to determine whether there is immunoreactive bFGF at the lumenal cell membrane. This will be an important issue for resolution by immunoelectron microscopy, since in vitro studies suggest that low affinity binding to heparan sulfate on the cell surface serves as a reservoir for basic FGF (37).

The absence of stain in the arterial smooth muscle layer would not have been predicted from studies of cultured smooth muscle cells (20). However, the result is consistent with our recent findings that freshly isolated rat aortic smooth muscle cells contain very little of these peptides compared with aliquots of the same cells in culture. Adventitial fibroblasts did exhibit bFGF immunoreactivity.

Cardiac myocytes also were immunoreactive for bFGF. The pattern was punctate but homogeneous throughout the cytoplasm. A few nuclei were stained. The presence of nuclear irbFGF in other cells may be cell specific or cell cycle specific (54).

Immunostaining for aFGF has not shown adequate sensitivity and specificity to date.

Possible functions of cardiac FGF peptides. The presence of cardiac FGF peptides naturally raises the question of their function. It is easy to imagine that these proteins might function in cardiac development, atherogenesis, the healing of myocardial infarction, the development of coronary collaterals in response to ischemia, or the development of myocyte hypertrophy or vascular smooth muscle proliferation in hypertension or hypertrophic cardiomyopathy. However, these conditions are rare or nonexistent in rats and dogs and yet we have found these peptides in these species as well. It may be that in the normal adult heart, as in the pituitary, bFGF serves a nonmitogenic endocrine (55) or neurotropic (56) function. There is also one report of vasoconstrictive activity by bFGF in helical strips of rat aorta (57). Alternatively, in light of bFGF's induction of the mesoderm $(6,7)$, its presence could simply be

Figure 6. Immunohistochemical staining with anti-bFGF ${ }_{1-24}$ in normal $250-\mathrm{g}$ rat LV. $A$, The brown reaction product, not seen with preimmune or peptide-absorbed antisera, or in sections prewashed with $2 \mathrm{M} \mathrm{NaCl}$, indicates presence of bFGF in cardiac myocytes and arterial endothelium. Faint staining is observed in capillary and venular endothelium in some assays, perhaps reflecting lot-to-lot variation in fixative and hyaluronidase. $(\times 1,500)$. $B$. The virtual absence of immunoreactivity when $2 \mu \mathrm{g}$ of hrbFGF was preadsorbed to $1 \mathrm{ml}$ of a 1:1,000 dilution of the primary antiserum $(\times 1,500)$. Three mast cells stain nonspecifically with the immunoperoxidase system because of their biotin content. 
a vestige of embryogenesis, or could serve to maintain some differentiated feature. For example, Gospodarowicz has shown that it maintains the monolayer property of cultured endothelial cells (8). It also increases their lifespan fourfold, to as many as 100 population doublings.

Despite the presence of large amounts of cardiac aFGF and bFGF, which not only enhance proliferation in vitro of endothelial and smooth muscle cells and fibroblasts, but also stimulate DNA synthesis in cultured cardiac myocytes (58), there is little vascular and no myocyte proliferation in the normal adult heart (26). Absence of FGF receptors is a possible explanation. We have found specific cardiac binding in vivo of aFGF (59). Although this binding was not competed by heparin, high affinity binding sites in normal heart tissue have not yet been demonstrated. Inhibition of endothelial proliferation may be due to transforming growth factor-beta (60) which we have identified in the heart (39). Heparin (61), laminin (62, 63 ), or other growth inhibitors may contribute to the terminal differentiation of cardiac myocytes in the presence of potent growth factors.

Future studies can be expected to clarify the roles of the FGF peptides in the heart. Such data could suggest potential therapeutic possibilities. For example, angiogenesis, wound healing, and regeneration are slow or incomplete in some settings, but can be accelerated by FGF peptides, or by heparin, with which they interact $(8,56,61,64)$. FGF-based therapies might be used to promote coronary collateral growth, to speed healing and prevent expansion and rupture in myocardial infarction, and conceivably, to promote myocyte regeneration.

Note added in proof. Immunoreactivity for bFGF has very recently been reported in nuclei and intercalated discs of cardiac myocytes in cryostat sections (Kardami, E., and R. R. Fandrich. 1989. Basic fibroblast growth factor in atria and ventricles of the vertebrate heart. J. Cell Biol. 109:1865-1875). We find both FGFs in nuclei in cryostat sections and in our formalin-fixed cultured myocytes (Speir, E., V. Tanner, S. Shrivastav, and W. Casscells, manuscript submitted for publication). Furthermore, bFGF and aFGF can both be purified from nuclei of cultured endothelial cells (Yu, Z.-X., S. Biro, V. Ferrans, and W. Casscells, manuscript submitted for publication). Kardami et al. could not find evidence of aFGF or TGF- $\beta$ in adult heart. The reasons for these discrepancies with our results are unclear.

\section{References}

1. Abraham, J. A., A. Mergia, J. L. Whang, A. Tumolo, J. Friedman, K. A. Hjerrild, D. Gospodarowicz, and J. C. Fiddes. 1986. Nucleotide sequence of a bovine clone encoding the angiogenic protein, basic fibroblast growth factor. Science (Wash. DC). 233:545-548.

2. Jaye, M., R. Howk, W. Burgess, G. A. Ricca, I. Chiu, M. W. Ravera, S. J. O'Brien, W. S. Modi, T. Maciag, and W. N. Drohan. 1986. Human endothelial cell growth factor: cloning, nucleotide sequence and chromosome localization. Science (Wash. DC). 233:541545.

3. Gospodarowicz, D., H. Bialecki, and T. K. Thakral. 1979. The angiogenic activity of the fibroblast and epidermal growth factor. Exp. Eye Res. 28:501-514.

4. Shing, Y., J. Folkman, R. Sullivan, C. Butterfield, J. Murray, and M. Klagsbrun. 1984. Heparin affinity: purification of a tumor-derived capillary endothelial cell growth factor. Science (Wash. DC). 22:12961298.

5. Thomas, K. A., M. Rios-Candelore, G. Gimenez-Gallego, J. DiSalvo, C. Bennett, J. Rodkey, and S. Fitzpatrick. 1985. Pure brainderived acidic fibroblast growth factor is a potent angiogenic vascular endothelial cell mitogen with sequence homology to interleukin 1. Proc. Natl. Acad. Sci. USA. 82:6409-6413.
6. Slack, J. M. W., B. G. Darlington, J. K. Heath, and S. F. Godsave. 1987. Mesoderm induction in early Xenopus embryos by heparin-binding growth factors. Nature (Lond.). 326:197-200.

7. Kimelman, D., and M. Kirschner. 1987. Synergistic induction of mesoderm by FGF and TGF-beta and the identification of an mRNA coding for FGF in the early Xenopus embryo. Cell. 51:869-877.

8. Gospodarowicz, D., N. Ferrara, L. Schweigerer, and C. Neufeld. 1987. Structural characterization and biological functions of fibroblast growth factor. Endocr. Rev. 8:95-114.

9. Vlodavsky, I., J. Folkman, R. Sullivan, R. Fridman, R. IshaiMichaeli, J. Sasse, and M. Klagsbrun. 1987. Endothelial cell-derived basic fibroblast growth factor: synthesis and deposition into subendothelial extracellular matrix. Proc. Natl. Acad. Sci. USA. 84:2292-2296.

10. Baird, A., and N. Ling. 1987. Fibroblast growth factors are present in the extracellular matrix produced by endothelial cells in vivo: implications for a role of heparinase-like enzymes in a neovascular response. Biochem. Biophys. Res. Commun. 142:428-435.

11. Schweigerer, L., G. Neufeld, J. Friedman, J. A. Abraham, J. C. Fiddes, and D. Gospodarowicz. 1987. Capillary endothelial cells express basic fibroblast growth factor, a mitogen that promotes their own growth. Nature (Lond.). 325:257-259.

12. Ferrara, N., L. Schweigerer, G. Neufeld, R. Mitchell, and D. Gospodarowicz. 1987. Pituitary follicular cells produce basic fibroblast growth factor. Proc. Natl. Acad. Sci. USA. 84:5773-5777.

13. Neufeld, G., N. Ferrara, L. Schweigerer, R. Mitchell, and D. Gospodarowicz. 1987. Bovine granulosa cells produce basic fibroblast growth factor. Endocrinology. 121:597-603.

14. Schweigerer, L., B. Malerstein, G. Neufeld, and D. Gospodarowicz. 1987. Basic fibroblast growth factor is synthesized in cultured retinal pigment epithelial cells. Biochem. Biophys. Res. Commun. 143:934-940.

15. Moscatelli, D., M. Presta, J. Joseph-Silverstein, and D. B. Rifkin. 1986. Both normal and tumor cells produce basic fibroblast growth factor. J. Cell. Physiol. 129:273-276.

16. Maciag, T., T. Mehlman, R. Friesel, and A. Schreiber. 1984. Heparin binds endothelial cell growth factor, the principal endothelial cell mitogen in bovine brain. Science (Wash. DC). 225:932-935.

17. D'Amore, P. A., B. M. Glaser, S. K. Brunson, and A. H. Fenselau. 1981. Angiogenic activity from bovine retina: partial purification and characterization. Proc. Natl. Acad. Sci. USA. 78:3068-3072.

18. Gautschi-Sova, P., Z.-P. Jiang, M. Frater-Schroder, and P. Bohlen. 1987. Acidic fibroblast growth factor is present in non-neural tissue: isolation and chemical characterization from bovine kidney. Biochemistry. 26:5844-5847.

19. Hauschka, P. V., A. E. Mavrakos, M. D. Iafrati, S. E. Doleman, and M. Klagsbrun. 1986. Growth factors in bone matrix. J. Biol. Chem. 261:12665-12674.

20. Winkles, J. A., R. Friesel, W. H. Burgess, R. Howk, T. Mehlman, R. Weinstein, and T. Maciag. 1987. Human vascular smooth muscle cells both express and respond to heparin-binding growth factor I. (endothelial cell growth factor). Proc. Natl. Acad. Sci. USA. 84:7124-7128.

21. Lobb, R. R., S. M. Rybak, D. K. St. Clair, and J. W. Fett. 1986. Lysates of two established human tumor lines contain heparin-binding growth factors related to bovine acidic brain fibroblast growth factor. Biochem. Biophys. Res. Commun. 139:861-867.

22. Vlodavsky, I., R. Fridman, R. Sullivan, J. Sasse, and M. Klagsbrun. 1987. Aortic endothelial cells synthesize basic fibroblast growth factor which remains cell-associated and platelet-derived growth factor-like protein which is secreted. J. Cell. Physiol. 131:402-408.

23. Moscatelli, D., J. Joseph-Silverstein, R. Manejias, and D. B. Rifkin. 1987. $M_{\mathrm{r}} 25,000$ heparin-binding protein from guinea pig brain is a high molecular weight form of basic fibroblast growth factor. Proc. Natl. Acad. Sci. USA. 84:5778-5782.

24. Baird, A., F. Esch, P. Mormede, N. Ueno, N. Ling, P. Bohlen, S.-Y. Ying, W. B. Wehrenberg, and R. Guillemin. 1986. Molecular characterization of fibroblast growth factor: distribution and biological activities in various tissues. Recent Prog. Horm. Res. 42:143-205.

25. Gospodarowicz, D. 1974. Localization of a fibroblast growth 
factor and its effect alone and with hydrocortisone on $3 \mathrm{~T} 3$ cell growth. Nature (Lond.). 249:123-127.

26. Messier, B., and C. P. Leblond. 1960. Cell proliferation and migration as revealed by radioautography after injection of thymidine- $\mathrm{H}^{3}$ into male rats and mice. Am. J. Anat. 160:247-285.

27. Ausprunk, D. H., D. R. Knighton, and J. Folkman. 1975. Vascularization of normal and neoplastic tissues grafted to the chick chorioallantois. Am. J. Pathol. 79:597-618.

28. Galloway, A. C., R. Pelletier, and P. A. D'Amore. 1984. Do ischemic hearts stimulate endothelial cell growth? Surgery (St. Louis). 96:435-438.

29. Weiner, H. L., and J. L. Swain. 1989. Acidic fibroblast growth factor mRNA is expressed by cardiac myocytes in culture and the protein is localized to the extracellular matrix. Proc. Natl. Acad. Sci. USA. 86:2683-2687.

30. Casscells, W., E. Speir, D. Nguyen, and E. Yang. 1987. Purification and characterization of heparin-binding polypeptide mitogens from human left ventricular myocardium. Clin. Res. 35:266A. (Abstr.)

31. D'Amore, P. A., and R. W. Thompson. 1987. Mechanisms of angiogenesis. Annu. Rev. Physiol. 49:453-464.

32. Quinckler, W., M. Maasberg, S. Bernotat-Danielowski, N. Luthe, H. S. Sharma, and W. Schaper. 1989. Isolation of heparin-binding growth factors from bovine, porcine and canine hearts. Eur. J. Biochem. 181:67-73.

33. Wadzinski, M. G., J. Folkman, J. Sasse, K. Devey, D. Ingber, and M. Klagsbrun. 1987. Heparin-binding angiogenesis factors: detection by immunological methods. Clin. Physiol. Biochem. 5:200-209.

34. Folkman, J., C. C. Haudenschild, and B. R. Zetter. 1979. Long-term culture of capillary endothelial cells. Proc. Natl. Acad. Sci. USA. 76:5217-5226.

35. Neufeld, G., and D. Gospodarowicz. 1987. Protamine sulfate inhibits mitogenic activities of the extracellular matrix and fibroblast growth factor, but potentiates that of epidermal growth factor. J. Cell. Physiol. 132:287-294.

36. Neufeld, G., and D. Gospodarowicz. 1985. The identification and partial characterization of the fibroblast growth factor receptor of baby hamster kidney cells. J. Biol. Chem. 260:13860-13868.

37. Moscatelli, D. 1987. High and low affinity binding sites for basic fibroblast growth factor on cultured cells: absence of a role for low affinity binding in the stimulation of plasminogen activator production by bovine capillary endothelial cells. J. Cell. Physiol. 131:123-130.

38. Albini, A., C. D. Mitchell, E. W. Thompson, R. Seeman, G. R. Martin, A. E. Wittek, and G. C. Quinnan. 1988. Invasive activity and chemotactic response to growth factors by Kaposi's sarcoma cells. $J$. Cell. Biochem. 36:369-376.

39. Thompson, N. L., F. Bazoberry, E. Speir, W. Cascells, V. J. Ferrans, K. C. Flanders, P. Kondaiah, A. G. Geiser, and M. B. Sporn. 1988. Transforming growth factor beta-1 in acute myocardial infarction in rats. Growth Factors. 1:91-99.

40. Dickson, C., and G. Peters. 1987. Potential oncogene product related to growth factors. Nature (Lond.). 326:833.

41. Taira, M., T. Yoshida, K. Miyagawa, H. Sakamoto, N. M. Terada, and T. Sugimura. 1987. cDNA sequence of human transforming gene hst and identification of the coding sequence required for transforming activity. Proc. Natl. Acad. Sci. USA. 84:2980-2984.

42. DelliBovi, P., A. M. Curatola, F. G. Kern, A. Grecs, G. M. Ittman, and C. Basilico. 1987. An oncogene isolated by transfection of Kaposi's sarcoma DNA encodes a growth factor that is a member of the FGF family. Cell. 50:729-737.

43. Zhan, X., B. Bates, X. Hu, and M. Goldfarb. 1988. The human FGF-5 oncogene encodes a novel protein related to fibroblast growth factors. Mol. Cell. Biol. 8:3487-3495.

44. Mormede, P., A. Baird, and P. Pigeon. 1985. Immunoreactive fibroblast growth factor (FGF) in rat tissues: molecular weight forms and the effects of hypophysectomy. Biochem. Biophys. Res. Commun. 128:1108-1113.

45. D'Amore, P., and D. Shepro. 1977. Stimulation of growth and calcium influx in cultured bovine aortic endothelial cells by platelets and vasoactive substances. J. Cell. Physiol. 92:177-184.
46. Ishikawa, F., K. Miyazono, U. Hellman, H. Drexler, C. Wernstedt, K. Usuki, F. Takaku, W. Risau, and C.-H. Heldin. 1989. Identification of biologic activity and the cloning and expression of plateletderived endothelial cell growth factor. Nature (Lond.). 338:557-562.

47. Calvo, B., M. Klagsbrun, S. E. Epstein, E. Speir, J. Sasse, J. Folkman, and W. Casscells. 1987. Isolation and characterization of a myocardial polypeptide that is mitogen for fibroblasts. J. Am. Coll. Cardiol. 9:155A. (Abstr.)

48. Kao, P. D., D. E. Rannels, and H. E. Morgan. 1976. Effects of anoxia and ischemia on protein synthesis in perfused rat hearts. Circ. Res. 38(Suppl. 1):124-130.

49. Hatt, P. Y., C. Ledoux, J.-P. Bovalet, and H. Guillemot. 1965. Lyse et synthese des proteines myocardique au cours de l'insuffisance cardiaque experimentale. Arch. Mal. Coeur Vaiss. 58:1703-1721.

50. Dillman, W. H., H. B. Mehta, A. Barrieux, B. D. Guth, W. E. Nelley, and J. Ross, Jr. 1986. Ischemia of the dog heart induces the appearance of cardiac mRNA coding for a protein with migration characteristics similar to heart shock/stress protein. Circ. Res. 59:113114.

51. Fox, P. L., and P. E. DiCorleto. 1984. Regulation of production of a platelet-derived growth factor-like protein by cultured bovine aortic endothelial cells. J. Cell. Physiol. 121:298-308.

52. Lobb, R. R. 1988. Thrombin inactivates acidic fibroblast growth factor but not basic fibroblast growth factor. Biochemistry. 27:2572-2578.

53. Gospodarowicz, D., and J. Cheng. 1986. Heparin protects basic and acidic FGF from inactivation. J. Cell. Physiol. 128:475-484.

54. Bouche, G., N. Gas, H. Prats, V. Baldin, J.-P. Tauber, J. Teissie, and F. Amalric. 1987. Basic fibroblast growth factor enters the nucleolus and stimulates the transcription of ribosomal genes in ABAE cells undergoing $G_{0}$ to $G_{1}$ transition. Proc. Natl. Acad. Sci. USA. 84:6770-6774.

55. Baird, A., P. Mormede, S.-Y. Ying, W. B. Wehrenberg, N. Ueno, N. Ling, and B. Guillemin. 1985. A non-mitogenic pituitary function of fibroblast growth factor: regulation of thyrotropin and prolactin secretion. Proc. Natl. Acad. Sci. USA. 82:5545-5549.

56. Walicke, P., W. M. Cowan, N. Ueno, A. Baird, and R. Guillemin. 1986. Fibroblast growth factor promotes survival of dissociated hippocampal neurons and enhances neurite extension. Proc. Natl. Acad. Sci. USA. 83:3012-3016.

57. Berk, B. C., R. W. Alexander, T. A. Brock, M. A. Gimbrone, Jr, and R. C. Webb. 1986. Vasoconstriction: a new activity for platelet-derived growth factor. Science (Wash. DC). 232:87-90.

58. Claycomb, W. C., and R. L. Moses. 1988. Growth factors and TPA stimulate DNA synthesis and alter the morphology of cultured terminally differentiated adult rat cardiac muscle cells. Dev. Biol. 127:257-265.

59. Rosengart, T. K., J. P. Kupferschmid, V. J. Ferrans, W. Casscells, T. Maciag, and R. E. Clark. 1988. Heparin-binding growth factor I (endothelial cell growth factor) binds to endothelium in vivo. J. Vasc. Surg. 7:311-317.

60. Baird, A., and T. Durkin. 1986. Inhibition of endothelial cell proliferation by type beta transforming growth factor: interactions with acidic and basic fibroblast growth factors. Biochem. Biophys. Res. Commun. 138:476-482.

61. Folkman, J., R. Langer, R. J. Linhardt, C. Haudenschild, and S. Taylor. 1983. Angiogenesis inhibition and tumor regression caused by heparin or a heparin fragment in the presence of cortisone. Science (Wash. DC). 221:719-725.

62. Ingber, D. E., J. A. Madri, and J. Folkman. 1987. Endothelial growth factors and extracellular matrix regulate DNA synthesis through modulation of cell and nuclear expansion. In Vitro (Rockville). 23:387-394.

63. Martin, G. R., and R. Timpl. 1987. Laminin and other basement membrane components. Annu. Rev. Cell Biol. 3:57-85.

64. Davidson, J. M., M. Klagsbrun, K. E. Hill, A. Buckley, R. Sullivan, P. S. Brewer, and S. C. Woodward. 1985. Accelerated wound repair, cell proliferation and collagen accumulation are produced by $a$ cartilage-derived growth factor. J. Cell Biol. 100:1219-1227. 